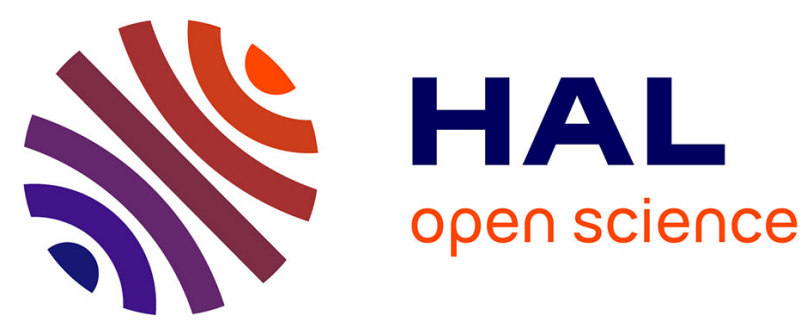

\title{
AEROGEL CATALYST MODIFICATION TO IMPROVE CATALYTIC STABILITY DURING THE NITROXIDATION OF PROPYLENE
}

\author{
M. Rahman, R. Willey, S. Teichner
}

\section{- To cite this version:}

M. Rahman, R. Willey, S. Teichner. AEROGEL CATALYST MODIFICATION TO IMPROVE CATALYTIC STABILITY DURING THE NITROXIDATION OF PROPYLENE. Journal de Physique Colloques, 1989, 50 (C4), pp.C4-7-C4-11. 10.1051/jphyscol:1989402 . jpa-00229477

\section{HAL Id: jpa-00229477 https://hal.science/jpa-00229477}

Submitted on 1 Jan 1989

HAL is a multi-disciplinary open access archive for the deposit and dissemination of scientific research documents, whether they are published or not. The documents may come from teaching and research institutions in France or abroad, or from public or private research centers.
L'archive ouverte pluridisciplinaire HAL, est destinée au dépôt et à la diffusion de documents scientifiques de niveau recherche, publiés ou non, émanant des établissements d'enseignement et de recherche français ou étrangers, des laboratoires publics ou privés. 
REVUE DE PHYSIQUE APPLIQUEE

Colloque C4, Supplément au $\mathrm{n}^{\circ} 4$, Tome 24, Avxil 1989

\title{
AEROGEL CATALYST MODIFICATION TO IMPROVE CATALYTIC STABILITY DURING THE NITROXIDATION OF PROPYLENE
}

\author{
M. RAHMAN, R.J. WILLEY* and S.J. TEICHNER* * \\ K.S.E., Amherst, Mass., U.S.A. \\ "Department of Chemical Engineering, Northeastern University, Boston, \\ Mass. , U.S.A. \\ ** University Claude Bernard, Lyon I, F-69622 Villeurbanne, France
}

Résumé - $\mathrm{L}^{\prime}$ introduction de $\mathrm{MgO}$ ou de $\mathrm{Fe}_{3} \mathrm{O}_{4}$ dans l'aérogel binaire $\mathrm{NiO} / \mathrm{Al}_{2} \mathrm{O}_{3}$ augmente très notablement la stabilite du catalyseur dans la nitroxydation du propylène.

Abstract - By introducing $\mathrm{MgO}$ or $\mathrm{Fe}_{3} \mathrm{O}_{4}$ into a binary $\mathrm{NiO} / \mathrm{Al}_{2} \mathrm{O}_{3}$ aerogel the catalytic stability in the nitroxidation of propylene may be dramatically improved.

\section{INTRODUCTION}

The nitroxidation of propylene over nickel oxide alumina aerogel catalysts, the combination of nitric oxide and propylene to form acrylonitrile, was first reported by $\mathrm{Zidan}$, et al. in $1977 / 1 /$ Recently, during an investigation of the mechanism of this reaction /2/, attempts were made to understand the nature of deactivation which occurred and to understand how it may be controlled by aerogel catalyst modifications /3/. Work has continued to model the rate of deactivation and to quantify the deactivation process which will be discussed below.

The nitroxidation reaction is :

$$
2 \mathrm{C}_{3} \mathrm{H}_{6}+3 \text { NO } \rightarrow 2 \mathrm{C}_{3} \mathrm{H}_{3} \mathrm{~N}+3 \mathrm{H}_{2} \mathrm{O}+1 / 2 \mathrm{~N}_{2}
$$

The product, acrylonitrile, is an important monomer used in further processing for the manufacturing of acrylic fibers, nylon-66, and several other polymeric compounds.

\section{EXPERIMENTAL}

Aerogel catalysts synthesis

The reference catalyst was a $1: 1$ atomic ratio of $\mathrm{Ni}$ to $\mathrm{Al}$ aerogel. The aerogel was formed by autoclaving a mixture of $5 \%$ nickel acetate tetrahydrate in methanol and $12.5 \%$ aluminum-tri-sec-butoxide in sec-butanol. The procedure was as follows: a solution of 12.5 8 aluminum-tri-sec-butoxide in sec-butanol was carefully made up and capped. A second solution of $5 \%$ nickel acetate tetrahydrate in methanol was made up. Additional water, required for the hydrolysis of the alumina, was added to the second solution.

Then the proper amount of the second solution was rapidly added to first solution which would give a resultant atomic ratio of $\mathrm{Ni}$ to $\mathrm{Al}$ of $1: 1$. An aluminum hydroxide precipitate formed immediately while the $\mathrm{Ni}$ ions remained in solution (the alcogel). This mixture was then placed into an autoclave and supercritically dried. The $\mathrm{Ni}$ ions deposited onto the alumina during the drying process. The final product was greyish black. X-ray and Raman analysis showed the composition to be amorphous alumina, nickel oxide and a surface nickel ions.

Other atomic ratios of $\mathrm{Ni}$ to $\mathrm{Al}$ investigated were $0.05,0.2,0.4,0.6$, and 0.86 . Another modification examined in the preparation of the $0.86 \mathrm{Ni}$ to Al aerogel was the addition of ammonia to solution 2 before addition to solution 1 . The color turned from green to blue for this solution, and the resultant aerogel had higher surface area of $426 \mathrm{~m}^{2} / \mathrm{g}$ versus 360 $\mathrm{m}^{2} / \mathrm{g}$ for the 0.86 material without ammonia. Further, evaluation of this aerogel showed tremendous activity for the cracking of propylene to methane with no activity for nitroxidation. Electron micrographs of this catalyst after testing showed a "peppered" surface indicating the agglomeration of $\mathrm{Ni}$ atoms into clusters. These agglomerations were not seen on the reference catalyst. 
Further aerogel modifications investigated were the substitution of magnesium or iron for a portion of the nickel content. Specific compositions made were $0.2 \mathrm{Mg}: 0.8 \mathrm{~N} 1: 1.0 \mathrm{Al}$ and 0.2 Fe: $0.8 \mathrm{~N} \pm: 1.0$.

The magnesium and iron solutions used in the alcogels solutions were $5 \%$ magnesium acetate tetrahydrate in methanol and $5 \%$ ferric acetylacetonate in methano1.

\section{Experimental test unit}

The experimental test unit consisted of a quartz reactor, a reactant mixture panel, and an analytical section. The quartz reactor was designed as an up flow reactor catalyst bed. An aerogel catalyst $(0.2 \mathrm{~g})$ was placed between two quartz fritted disks (volume approximately $10 \mathrm{~cm}^{3}$ ) which kept the catalyst inside the quartz reactor. The reactor was heated by a quartz tube oven. All reaction measurements for thís work were conducted at a catalyst temperature of $410^{\circ} \mathrm{C}\left( \pm 2^{\circ} \mathrm{C}\right)$.

The reactant gas feed mixture was $2 \mathrm{cc} / \mathrm{min}$ nitric oxide, $18 \mathrm{cc} / \mathrm{m}$ in propylene (CP grade), and $10 \mathrm{cc} / \mathrm{min}$ helium $\left(1: 9: 5 \mathrm{NO}: \mathrm{C}_{3} \mathrm{H}_{6}: \mathrm{He}\right)$. These flow rates were constant for all evaluations except in the evaluations where moisture was added when $(0.2 \mathrm{Fe}: 0.8 \mathrm{~N} 1: 1.0 \mathrm{Al}$ and $1: 1$ $\mathrm{Ni}: \mathrm{Al}$ ) helium was passed through a packed column with water. The saturated helium was then blended with the feed mixture at a rate of $10 \mathrm{cc} / \mathrm{min}$. All aerogel catalysts received similar pretreatments of pure oxygen $(30 \mathrm{cc} / \mathrm{min})$ at $410^{\circ} \mathrm{C}$ for 24 hours. Thirty minutes prior to a run, the oxygen flow was switched to pure helium to prevent any explosions before switching to the propylene reactant mixture.

Gas analysis of the effluent gas stream was done by two gas chromatographs and a quadrupole mass spectrometer. For analysis of hydrocarbons, a gas chromatograph equipped with a FID was used. Initially, the FID chromatograph was a Perkin Elmer Model 3920 with a 1/8" $0 . D$. 2 m column packed with Porapak QS. Later a Hewlett-Packard Model 5890 gas chromatograph was used. Oven temperature for the gas chromatographs was set isothermally at $120^{\circ} \mathrm{C}$. Sampling was done with $1 \mathrm{cc}$ gas chromatograph sample loop placed in line with the effluent reactor lines. Attached to the Hewlett-Packard chromatograph was a Hewlett Packard Model 3393-A integrator.

For analysis of nitric oxide, oxygen, carbon dioxide, and other inorganic gases, an Antek Model 300 gas chromatograph with TCD was used. This chromatograph had a 1/4" $0 . \mathrm{D}$. $2.5 \mathrm{~m}$ column packed with Porapak QS. It was operated isotherma1ly at $120^{\circ} \mathrm{C}$. Further details about the gas chromatograph operating conditions are presented in $/ 2 /$.

\section{Deactivation analysis - Relevant equations}

The modeliing of the deactivation reported below can be described by a concentration independent deactivation site balance : $1 . e$. ,

$$
\mathrm{dS} / \mathrm{dt}=-\mathrm{k}_{\mathrm{d}} \mathrm{S}
$$

where $S$ is the concentration of active sites per gram of catalyst and $k_{d}$ is the deactivation rate constant. The lower $k_{d}$, the more stable the catalyst. Defining activity, $a$, as the ratio of the rate at any time $\left(t-t_{p}\right)$ to the peak rate observed at time $t_{p}$ and assuming that rate is proportional to the concentration of active sites then the following activity equation results :

$$
\mathrm{da} / \mathrm{dt}=-\mathbf{k}_{\mathrm{d}^{\mathrm{a}}}
$$

whtch integrates to:

$$
a=r / r_{\text {peak }}=\exp \left(-k_{d} t_{d}\right)
$$

where $r$ is the rate of acrylonitrile formation in moles/g/sec and $t_{d}=\left(t-t_{p}\right)$ is the $t \pm m e$ after the peak activity was observed. $t_{d}=0$ is the time when the rate of formation to acrylonitrile equals the maximum. Thus, $k_{d}$ for various aerogels and run conditions can be determined by least squares analysis for the $r / r_{\text {peak }} v s$. $t_{d}$ data and qualitative comparison 
can be made.

\section{Results and dfscusston}

The evaluation of $1: 1 \mathrm{~N} 1$ to $\mathrm{Al}$ aerogel catalyst for nitroxidation of propylene is as shown in Fig. 1. Focusing on the top curve in Fig. 1 which represents results for the reference catalyst, $1: 1$ Ni to Al, the first 20 minutes of the run shows a surface oxtdation adjustment period.

Because the aerogel is oxidized with pure oxygen for a period of 24 hours prtor to testing, the surface contains a surplus of oxygen whtch oxidizes propylene to carbon dioxide. As the run continues, the catalyst is reoxidized by nitric oxide which introduces nitrogen to the surface and propylene becomes more preferably oxidized to acrylonttrile. Further, partial oxtdiation is preferred over total oxidation because the mixture is severely oxygen lean ( 1 to 9 for NO to $\mathrm{C}_{3} \mathrm{H}_{6}$ ). Product distrłbution after 20 minutes was approximately $74 \%$ acrylonftrile, $26 \%$ acetonftrile, and $8 \%$ carbon dioxide. Product distribution continued to improve to values of approximately $90 \%$ acrylonitrile, $5 \%$ acetonitrile, and $5 \%$ carbon dioxide by the end of a 3 hour evaluation.

The discouraging result was a $45 \%$ decline in acrylonftrile production over the three hour test period from its peak value.

Nickel is a known hydrocracking catalyst and a product of cracking Is surface carbon and carbon filaments which grow on the surface. Carbon deposition was confirmed in post testing by passing a $5 \%$ oxygen in helium mixture over the catalyst and detecting carbon dioxide. Further, catalyst examination by electron micrographs confirmed the presence of carbon filaments with metallic nickel centers. Therefore, decreasing nickel content was the intital approach investigated for stabflity improvement.

Rate $\times 10-8 \mathrm{~g}-\mathrm{mole} / \mathrm{g} \mathrm{sec}$

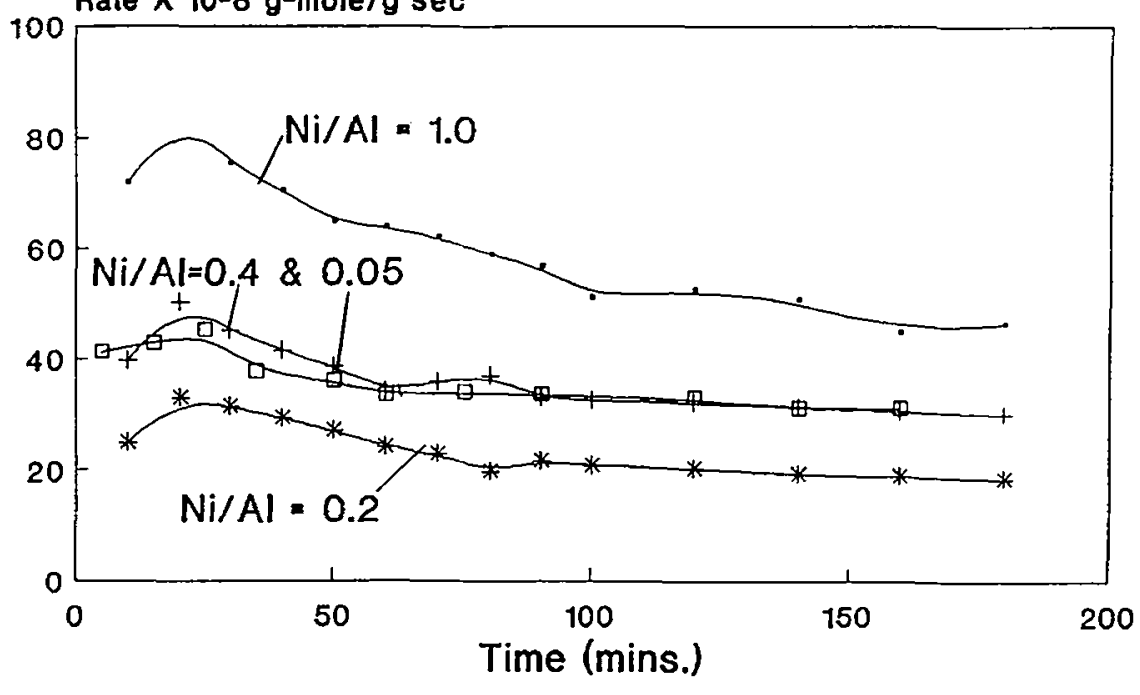

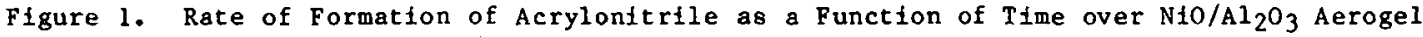
Catalysts with Different Nickel to Aluminum Atomic Ratios.

The influence of $\mathrm{N} \perp$ to Al ratto on catalyst stability is shown in Table 1 and Figure 1 for 4 levels of $\mathrm{N} I$ to $\mathrm{Al}$ ratios. For the ratios of $0.2,0.4$, and $1.0 \mathrm{~N} 1$ to Al, percent activicy retained over three hours is similar at $56 \%, 59 \%$, and $58 \%$, respectively and $k_{d}$ ranged from 0.142 to $0.191 \mathrm{hr}^{-1}$. Further, the peak activity per gram of nickel was similar 
for the three ratios at $2.52,2.82$, and $3.27 \mu$ moles/g Ni sec. These results suggest the active site that is related to $\mathrm{NiO}$. However, evaluation of the $0.05 \mathrm{Ni}$ to Al ratio gave a different trend. First its overall activity was superior to the $0.2 \mathrm{Ni}$ to $\mathrm{Al}$ aerogel and further it nearly matched the activity achieved with the $0.4 \mathrm{~N} I$ to Al aerogel. Its peak activity per gram of nickel was 16.27 moles/g N 1 sec. The $0.05 \mathrm{~N} \pm$ to Al aerogel had poorer selectivity, however. It was nevertheless a more stable material retaining $69 \%$ of $1 t s$ activity over a 3 hour run. The results suggest that the active site for nitroxidation is more than just $\mathrm{N} i \mathrm{O}$ and that the support, alumfna, piays a role.

\section{Influence of $\mathrm{Mg}$ and $\mathrm{Fe}$ on catalyst stability}

An aerogel catalyst was made with $0.2 \mathrm{Mg}$ substituted for $0.2 \mathrm{Ni}$ to give a resultant aerogel composed of $0.2 \mathrm{Mg}: 0.8 \mathrm{Ni}: 1.0 \mathrm{Al}$. This catalyst gave the best stability over a three hour period with no loss in activity over three hours.

overall, the Mg containing aerogel had the lowest deactivation rate constant of $0.058 \mathrm{hr}-1$. The explanation of why magnesium improved the stability is as follows. Catalytic activity for the cracking of hydrocarbons occurs over alumina-silica catalysts, and it has been shown that this activity is difectly related to acidity level $/ 4 /$.

The addition of basic magnesium ( $\mathrm{MgO}$ ) neutralizes actdity due to alumina and lowers cracking activity, therfore increasing stability. Thus, the deactivation process is partially related to the acidity of the aerogel.

Another aerogel catalyst was made with $0.2 \mathrm{Fe}$ substituted for $0.2 \mathrm{Ni}$ to give a resultant aerogel composed of $0.2 \mathrm{Fe}: 0.8 \mathrm{Ni}: 1.0 \mathrm{Al}$. This catalyst's stability was poorer than the $\mathrm{N} \pm / \mathrm{Al}$ aerogel $\left(\mathrm{k}_{\mathrm{d}}=0.23 \mathrm{hr}^{-1}\right)$. The motive to include fron in the aerogel catalyst was to provide an alternative to the Boudouard reaction $\left(2 \mathrm{CO} \rightarrow \mathrm{C}(\mathrm{s})+\mathrm{CO}_{2}\right)$, a source of surface carbon, by promoting an alternative reaction path for $C 0$ via the water gas shift reaction, $\mathrm{CO}+\mathrm{H}_{2} \mathrm{O}=\mathrm{CO}_{2}+\mathrm{H}_{2}$. Further testing in which moisture was added to the feed showed a dramatic improvement in stability. $k_{d}$ decreased by a factor 4 to $0.062 \mathrm{hr}^{-1}$ and the catalyst rivals. the stabililfty of the $\mathrm{Mg}$ containing aerogel. However, in comparing the peak activity between the magnesium and the fron containing aerogels, the magnesium aerogel is about a factor 2 better.

Table 1 : Deactivation Constants for Various Aeroge1 Catalysts Investigated for the Nitroxidation of Propylene to Acrylonitrile.

\begin{tabular}{|c|c|c|c|c|c|}
\hline Catalyst & $\begin{array}{l}\text { Atomic } \\
\text { Ratio } \\
\text { of the } \\
\text { Metalitc } \\
\text { Components }\end{array}$ & $\begin{array}{l}\text { Molsture } \\
\text { Content } \\
\text { In the } \\
\text { Reactant } \\
\text { s Feed } 1 \text { ) }\end{array}$ & $\begin{array}{l}\mathrm{k}_{\mathrm{d}} \\
\mathrm{hr} \mathrm{r}^{-1}\end{array}$ & $\begin{array}{c}\text { Peak } \\
\text { Activity } 2) \\
\times 10^{-8}\end{array}$ & $\begin{array}{l}\text { Activity } \\
\text { After } \\
3 \text { Hours } \\
\times 10^{-8}\end{array}$ \\
\hline $\begin{array}{c}\mathrm{N} 10 / \mathrm{Al}_{2} \mathrm{O}_{3} \\
\mathrm{~N} \pm 0 / \mathrm{Al}_{2} \mathrm{O}_{3} \\
\mathrm{NiO} / \mathrm{Al}_{2} \mathrm{O}_{3} \\
\mathrm{~N} 1 \mathrm{O} / \mathrm{Al}_{2} \mathrm{O}_{3} \\
\mathrm{~N} \pm 0 /\left(\mathrm{MgO}+\mathrm{Al}_{2} \mathrm{O}_{3}\right) \\
\left(\mathrm{N} \pm 0+\mathrm{Fe}_{3} \mathrm{O}_{4}\right) / \mathrm{Al}_{2} \mathrm{O}_{3} \\
\mathrm{~N} 10 / \mathrm{Al}_{2} \mathrm{O}_{3} \\
\left(\mathrm{~N} \pm 0+\mathrm{Fe}_{3} \mathrm{O}_{4}\right) / \mathrm{Al}_{2} \mathrm{O}_{3}\end{array}$ & $\begin{array}{c}1: 1 \\
0.4: 1 \\
0.2: 1 \\
0.05: 1 \\
0.8: 0.2: 1 \\
0.8: 0.2: 1 \\
1: 1 \\
0.8: 0.2: 1\end{array}$ & $\begin{array}{l}0.00 \\
0.00 \\
0.00 \\
0.00 \\
0.00 \\
0.00 \\
2.66 \\
2.66\end{array}$ & $\begin{array}{l}0.191 \\
0.142 \\
0.149 \\
0.160 \\
0.058 \\
0.230 \\
0.105 \\
0.062\end{array}$ & $\begin{array}{l}83.8 \\
50.3 \\
32.8 \\
45.2 \\
81.8 \\
83.2 \\
97.9 \\
41.6\end{array}$ & $\begin{array}{l}46.3 \\
30.0 \\
18.4 \\
31.1 \\
81.8^{37} \\
53.0 \\
59.0 \\
31.4\end{array}$ \\
\hline
\end{tabular}

1) $\mathrm{k} \mathrm{pa}$

2) $\mathrm{g} \mathrm{mole} / \mathrm{cm} 3 / \mathrm{g} / \mathrm{sec}$

3) the activity was observed for $48 \mathrm{~h}$

Since the addition of molsture to the feed stream improved the stability of iron containing aerogel an evaluation with moisture added was performed on the reference catalyst, 1:1 $\mathrm{N} \pm / A 1$. The results of this modification was encouraging with the highest peak rate observed for any of the aerogels investigated and $k_{d}$ decreasing from $0.191 \mathrm{hr}^{-1}$ (table 1 ) to 0.105 $\mathrm{hr}^{-1}$. 


\section{Carbon monoxide used as a molecular probe}

Further evfdence that the Boudouard reaction is the major source of deactivation was established by flowing a $5 \%$ carbon monoxide in helium stream across the $1: 1 \mathrm{Ni} / \mathrm{Al}$ aerogel at $410^{\circ} \mathrm{C}$. The catalyst deactivated and $k_{d}$ was $0.23 \mathrm{hr}^{-1}$. This value of the deactivation rate constant compares with the value for iron containing aerogel shown in Table 1 . When a mixture of $5 \%$ carbon monoxide and $5 \%$ nitric oxide in helium was flowed across the catalyst the deactivation rate constant decreased by a factor of 2 to $0.12 \mathrm{hr}^{-1}$. The presence of nitric oxide provided an alternative path for carbon monoxide oxidation in which no carbon was deposited on the surface.

\section{CONCLUSIONS}

1. Stability of nickel oxide alumina aerogel catalysts is not directly related to $\mathrm{Ni}$ content. The deactivation rate constants, $\mathrm{k}_{\mathrm{d}}$, range from 0.160 to $0.191 \mathrm{hr}^{-1}$.

2. The introduction of magnesia into the nickel-oxide-alumina aerogel catalyst improved the stability, $\mathrm{k}_{\mathrm{d}}=0.058 \mathrm{hr}^{-1}$, by lowering the aerogel's surface acidity.

3. The introduction of iron into the nickel oxide-alumina aerogel catalyst decreased stability for a dry feed mixture, $k_{d}=0.230 \mathrm{hr}^{-1}$, and improved stability for a moist feed mixture, $\mathrm{k}_{\mathrm{d}}=0.061 \mathrm{hr}^{-1}$. This is because a suspected product intermediate, carbon monoxide, reacts via the Boudouard reaction in the first case depositing surface carbon and reacts via the water gas shift reaction in the second case.

4. Deactivation via the Boudouard reaction was further substantiated by flowing carbon monoxide across the catalyst and measuring a deactivation rate of $0.23 \mathrm{hr}^{-1}$.

\section{ACKNOWLEDGEMENT}

This material is based upon work supported by the National Sclence Foundation under Grant CPE 84-04340. The authors also wish to acknowledge E.I. DuPont de Nemours and Company and the Cabot Foundation for partial financial assistance in carrying out this project and IBM company for the IBM scholar fund.

\section{REFERENCES}

$/ 1 /$ Zidan, F., Pajonk, G.M., Germain, J.E. and Teichner, S.J., Buil. Soc. Chim. Fr., (1977), 603.

/2/ Rahman, M., Ph.D. Dissertation, Northeastern University, Boston, MA 1988.

/3/ Rahman, M., Willey, R.J. and Teichner, S.J., Applied Catalysis, 36 (1988), 209.

/4/ Satterfield, C.N., Heterogeneous Catalysis in Practice, McGraw-Hi11, 1980, 159. 